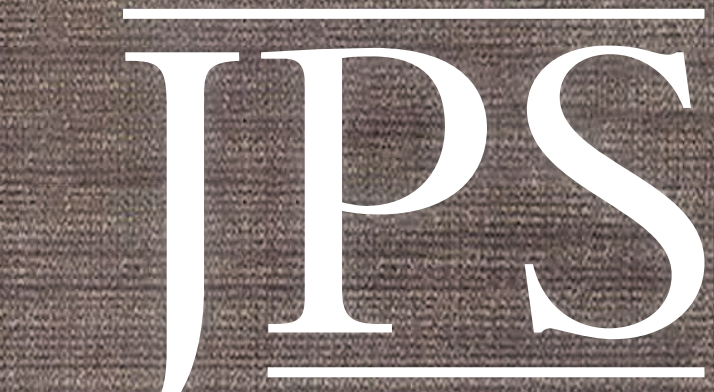

The Journal of the Polynesian Society

잔. (1) $-12 x^{2}(5)$

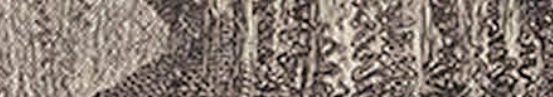
4 in






\title{
PANPIPES AND CLUBS: \\ EARLY IMAGES OF TANNA ISLANDERS
}

\author{
LAMONT LINDSTROM \\ University of Tulsa
}

\begin{abstract}
William Hodges, James Cook's artist on his second voyage, produced notably popular and influential drawings and paintings. These included several illustrations of Tanna Islanders (Vanuatu) that shaped European visions of the island from the 1770s through the 1830s, after which they were supplanted by Christian missionary depictions. Influenced by neoclassicist artistic convention, Hodges's engravings, which subsequently were much copied, commonly paired panpipes with clubs in islander hands. A chain of early engravings that feature panpipes and clubs reveals an initial heroic vision of natural island dignity, as both these accessories evoked European classical ideals. Although subsequent Christian and social evolutionary views later disavowed noble savage tropes, these persist in contemporary touristic appreciation of island musical talent and tradition.
\end{abstract}

Keywords: island imagery, William Hodges, music, panpipes, clubs, Tanna, Vanuatu

James Cook and his second expeditionary crew were the first Europeans to land on Tanna Island (Vanuatu). The voyage also produced the first illustrations of the island and its inhabitants. HMS Resolution anchored from 5 to 20 August, in Tanna's best harbour, which Cook would name after his ship. Artist William Hodges was on board, along with naturalist Johann (John) Reinhold Forster and his son Georg (George), who came along to draw the specimens his father collected. Cook's first Pacific voyage had likewise included several artists and draughtsmen employed either by the Admiralty or by Joseph Banks, the enlightened dilettante who, along with his party of natural scientists and servants, had squeezed onto Cook's original ship, Endeavour.

Charts, paintings and prints from Cook's three expeditions both served naval and scientific interests and fed increasing popular curiosity about distant shores. ${ }^{1}$ William Hodges, on the second voyage, produced notably popular and influential drawings and paintings. These included several illustrations of Tanna Islanders that shaped European visions of the island from the 1770s through the 1830s, after which they were supplanted by Christian missionary depictions. Influenced by neoclassicist artistic convention, Hodges's engravings, which subsequently were much copied, commonly paired panpipes with clubs in islander hands. Both these accessories evoked 
classical ideals. Although Christian and social evolutionary views later reworked earlier visions of nobly musical islanders, these persist and shape contemporary touristic appreciation of island musical talent and tradition.

Two previous expeditions before Cook's had chanced upon Vanuatu, but neither produced much graphic imagery or called at Tanna. Spanish/ Portuguese navigator Pedro Fernández de Quirós sailed through the archipelago's northern islands in 1606, but his charts and several drawings the voyage produced remained secreted in Spanish and Church archives. Quirós's narrative remained unpublished until 1876 (Kelly 1966: 6). French explorer Louis-Antoine de Bougainville also passed through northern Vanuatu in 1768, a few years before Cook. This voyage generated fewer island images insofar as Bougainville "did not take a competent natural history draughtsman with him. His naturalist, Philibert Commerson, though well-trained and enthusiastic, possessed neither the patience nor the skills of a good scientific draughtsman" (Smith 1985: 7).

Art historian Bernard Smith concludes that "it was left therefore to Banks to establish the value in practice of taking skilled artists on scientific voyages and of collating verbal and visual observations" (1985: 7), and that "the appointment of naturalists and artists became thenceforth a normal feature of the organization of scientific voyages" (p. 54). When Banks declined to participate in Cook's second voyage following a dispute about space on board allotted to his scientific party, the Admiralty appointed William Hodges and Johann Forster (travelling with his son Georg) as voyage artist and naturalist (Hoare 1967). Resolution thus anchored at Tanna carrying a cargo of cannon and muskets but also inks, chalk, crayons and paints.

\section{VIRTUAL GREEKS}

Smith (1985, 1992; Joppien and Smith 1985) has cogently analysed the "European vision" that shaped the images of islands and islanders produced during Cook's three voyages. Smith explores tensions between the demands of emergent scientific illustration and the genre constraints of neoclassical representation, but also the effect of Pacific experience on these conventions. There was notably, in Cook's time, lively interest in classicism. Island visions were doubly influenced by Enlightenment attention to Europe's classical roots. Cook and other eighteenth-century voyagers who encountered Pacific Islanders at least occasionally presumed these to resemble ancient Greeks, although those in Cook's party were more inclined to perceive Hellenic echoes in Polynesian Tahiti and Tonga than they were later on Tanna. Second, by the later eighteenth century, neoclassicist artistic conventions dominated graphic representation. "The ancient Greeks were seen as noble and refined ... and a model against which all other art should be measured" (Schneiderman 2014: 14; but see Campbell 1980). Even when Europeans 
encountered islanders who were clearly unbecoming of some classical ideal, they nonetheless drew on neoclassical conventions graphically to depict them.

I draw on Smith to examine a series of depictions of Tannese men and women, based originally on William Hodges's work, and subsequently redrawn and republished from 1777 through the 1830s. Hodges studied under several London artists including Giovanni Battista Cipriani, and he was schooled in neoclassicist style. His artistic visions of Tannese men and women were for many years recycled and repurposed. In 1841, with illustrative remembrance of the death of missionary John Williams on Erromango, just north of Tanna, Hodges's nobler island views yielded to a second stream of Pacific imagery that occluded previous classical allusions. This drew on a new, Christian sort of European vision and also on developing social evolutionary theory wherein distant others were taken to be mere lowly savages needing tutoring and salvation.

During his two weeks on Tanna in 1774, Hodges wandered about Port Resolution's shores sketching people and the landscape. Back home in Britain, he drew on these sketches to create oil paintings and drawings, several of these reproduced as engravings in Cook's 1777 published journal of the voyage, and then subsequently copied and modified elsewhere. Hodges's artistic sensibilities are evident in his work. Despite marked as "Drawn from Nature", for example, his Man of the Island of Tanna and Woman of the Island of Tanna evoke classical prototypes (Figs 1 and 2; see Jolly 1992: 347-48; 2009: 82).

Whoever (perhaps engraver George Noble) subsequently redrew these portraits for George William Anderson's (1784-1786) serial retelling of Cook's voyages made Hodges's Tanna man and woman appear even more classically European (Schneiderman 2014: 2) (Fig. 3). ${ }^{2}$

Hodges's landscape View in the Island of Tanna also displays similar artistic tension between the "grand style versus the topographic" (Joppien and Smith 1985: 92). This features a family group in a pastoral landscape (Fig. 4). As in his The Landing on Erramanga, Hodges here "adopted classic poses, such as the Discobolos and the Borghese Gladiator, to portray the islands" (pp. 94-95; see Guest 1989: 43). The foregrounded man, for example, in contrapposto and surrounded by women with children, leans on a huge club.

Printed versions of Hodges's work, to be fair, depended on the work of journeyman engravers such as William Wollett, James Basire (or possibly his apprentice William Blake) and John Keyse Sherwin. These London artists drew upon their own artistic conventions to transform field drawing and studio painting into engraving. As Smith concluded, "the canons of taste operated powerfully to transform the field studies into acceptable imagery" (1992: 179). The neoclassicist artistic canons of the time ennobled both islanders and Oceanic landscapes, rendering these accessible to contemporary consumers. 



Figures 1 and 2. Man of the Island of Tanna; Woman of the Island of Tanna, engravings by J. Basire after W. Hodges (Cook 1777: plates 26, 45).

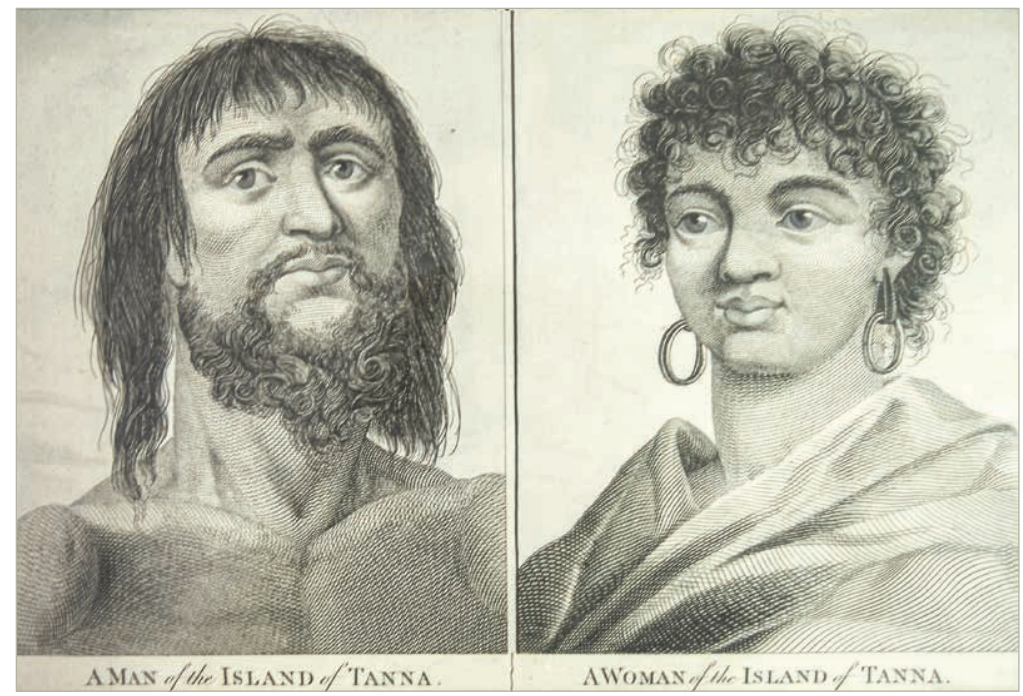

Figure 3. Man of the Island of Tanna/Woman of the Island of Tanna in Anderson (1784-1786). 


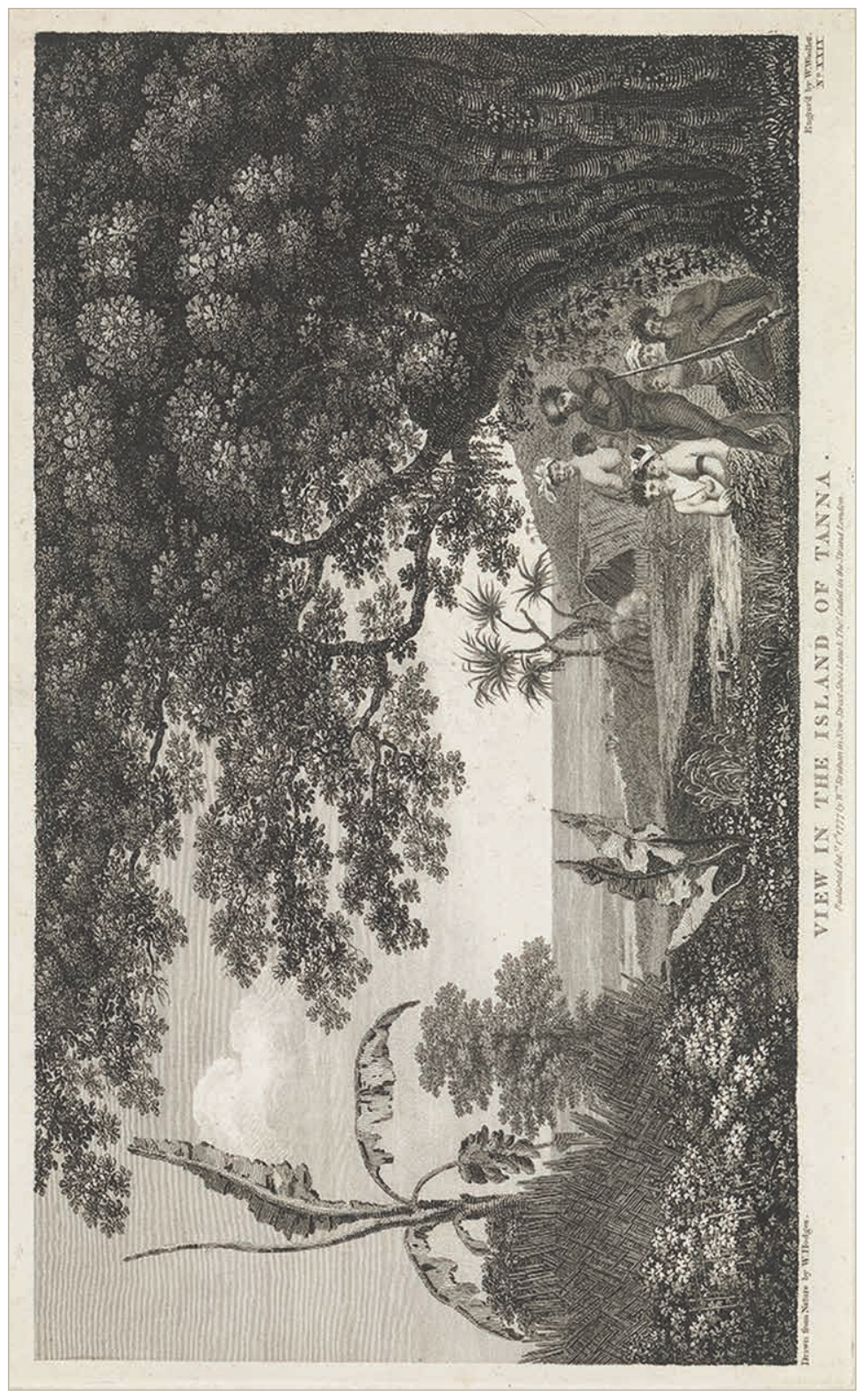

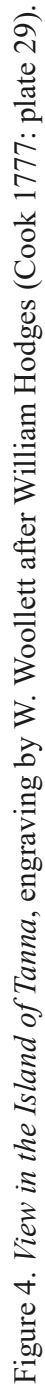




\section{PANPIPES AND CLUBS}

We might note emblematic material objects that Hodges and his copyists chose to include in their island portraits and views. Derivational island portraits would focus mainly on native clothing and "exotic facial ornaments" (Anderson 2017; Morrell 2010: 70), but artists also placed stereotypical objects in Tannese hands - notably panpipes and clubs.

Clubs were the more obvious artistic choice. Narrative description and accompanying graphic representation of weaponry within voyage journals and chronicles reflected the Admiralty's strategic concerns. Cook's instructions during his first voyage directed him "to observe the Genius, Temper, Disposition and Number of the Natives" (Smith 1985: 16), and he and the scientists on board all took notes about the relative friendliness or bellicosity of islanders the voyagers encountered across the Pacific, including calculation of the quality of their weaponry (Jolly 1992: 338). These strategic and ethnographic interests shaped second-voyage attentiveness as well. Cook, the Forsters and other voyage chroniclers all described a variety of clubs, spears, bows and arrows, slings and other armaments as Resolution crossed the Pacific. ${ }^{3}$ Cook (1961: 506-7) dedicated a couple of pages to Tanna weaponry in his published journal. Hodges (and his engraver, J.K. Sherwin) depicted several upraised Tannese clubs and spears in The Landing at Tanna, One of the New Hebrides (Cook 1777: plate 59), and also muskets in the hands of Cook's marines. Johann Forster produced a rough sketch of five Tanna clubs with accompanying descriptions (Hoare 1982: 625, also fig. 37; Joppien and Smith 1985:233). All who could, moreover, including many ordinary seamen, avidly collected whatever curiosities that islanders could be enticed to hand over. Clubs, spears, bows and arrows were among the most common of these.

The club, for Hodges and his copyists, signified accepted aspects of islander character and "temper" and also graphically illustrated frequent conflict and other nervous encounters reported in voyage chronicles. Observations of island clubs and other simple weaponry also spurred classical associations. Cook quoted his astronomer, William Wales, on Tannese expertise with spears. When Wales saw "what these people can do with their wooden ones", he was convinced of Homer's accounts of heroic feats (Cook 1961: 507). If Hodges's clubs suggested islanders' possibly violent character, his art ennobled their ferocity.

But what about panpipes? If clubs signalled an essential native wariness and occasional although heroic belligerence, panpipes implied pastoral idylls, evoking haunting tones that enlivened romanticised landscapes. Vanuatu's musicians fabricate a range of instruments including bamboo flutes, rattles, shell trumpets and the large carved slit drums famous in the north-central part of the archipelago. Cook and crew, however, had little 
chance to collect examples of these during Resolution's short anchorages off Malakula, Erromango or Espiritu Santo. Only panpipes became a recurrent musical motif in voyage imagery.

The British arrived with a general interest in music (Andersen 1932). Both the Royal Society and the Admiralty advised Cook to employ music to soothe and create rapport with islanders during first encounters (Agnew 2001: 6). Resolution's bagpipers, pipers and fiddlers performed at several of the ship's ports of call. Voyage chroniclers, moreover, appreciated island music "relative to its context, but also imposed their own interpretive criteria, resulting in a hierarchical ordering of not only indigenous musical traditions, but of the islanders themselves" (p. 18). Within this Oceanic musical appraisal Tanna finished well, at least according the critical ear of Georg Forster.

Voyage gentlemen, artists and scientists would have been schooled in musical appreciation, but Georg Forster's particular attention to music also may have been encouraged by his friendship with young James Burney. Burney, son of English musicologist and church organist Charles Burney, served as a lieutenant on Adventure, the expedition's second ship (Irving 2005: 208). The Forsters, Cook and the crew enthusiastically collected musical instruments, as they did weaponry, as exotic curiosities, including Tahitian nose flutes and Māori "trumpets" (p. 207). Back in Britain, these instruments invited scholarly interest: "One of the earliest articles on Polynesian instruments [collected during Cook's first voyage] described music systems of two Tongan panpipes and a Tahitian nose flute" (Kaeppler 1978: 57; see Steele 1775).

On Tanna, Georg Forster, along with fellow voyage naturalist Anders Sparrman, swapped songs with Port Resolution villagers. Forster wrote:

As I happened to hum a song, many of them very eagerly intreated me to sing to them, and though not one of us was properly acquainted with music, yet we ventured to gratify their curiosity, and in fact, offered them a great variety of airs. Some German and English songs, especially of the more lively kind, pleased them very much; but Dr. Sparrman's Swedish tunes gained universal applause ... When we had performed, we desired them in return to give us an opportunity of admiring their talents, and one of them immediately began a very simple tune; it was however harmonious, and, as far as we could judge, superior to the music of all the nations in the tropical part of the South Sea, which we had hitherto heard. (Forster 2000: 534-35; see also Agnew 2001: 15)

Passing time with Forster, the Tannese had with them at least one panpipe: "Our friendly natives likewise produced a musical instrument, which consisted of eight reeds, like the syrinx of Tonga-Tabboo, with this difference, that the reeds regularly decreased in size, and comprehended an octave, though the single reeds were not perfectly in tune" (Forster 2000: 535). ${ }^{4}$ This 
instrument, or another like it, was carried back to Resolution as it features in an engraving produced to illustrate Cook's 1777 voyage account. This engraving, Weapons, \&c at Mallicolo and Tanna, featured the "musical reeds" alongside a Tanna club (and also a bow, arrow and nose ornament), a material arrangement suggesting the evident salience of both island weapons and music - clubs and panpipes - within European visions of islanders (Fig. 5; Andersen 1932: 23).

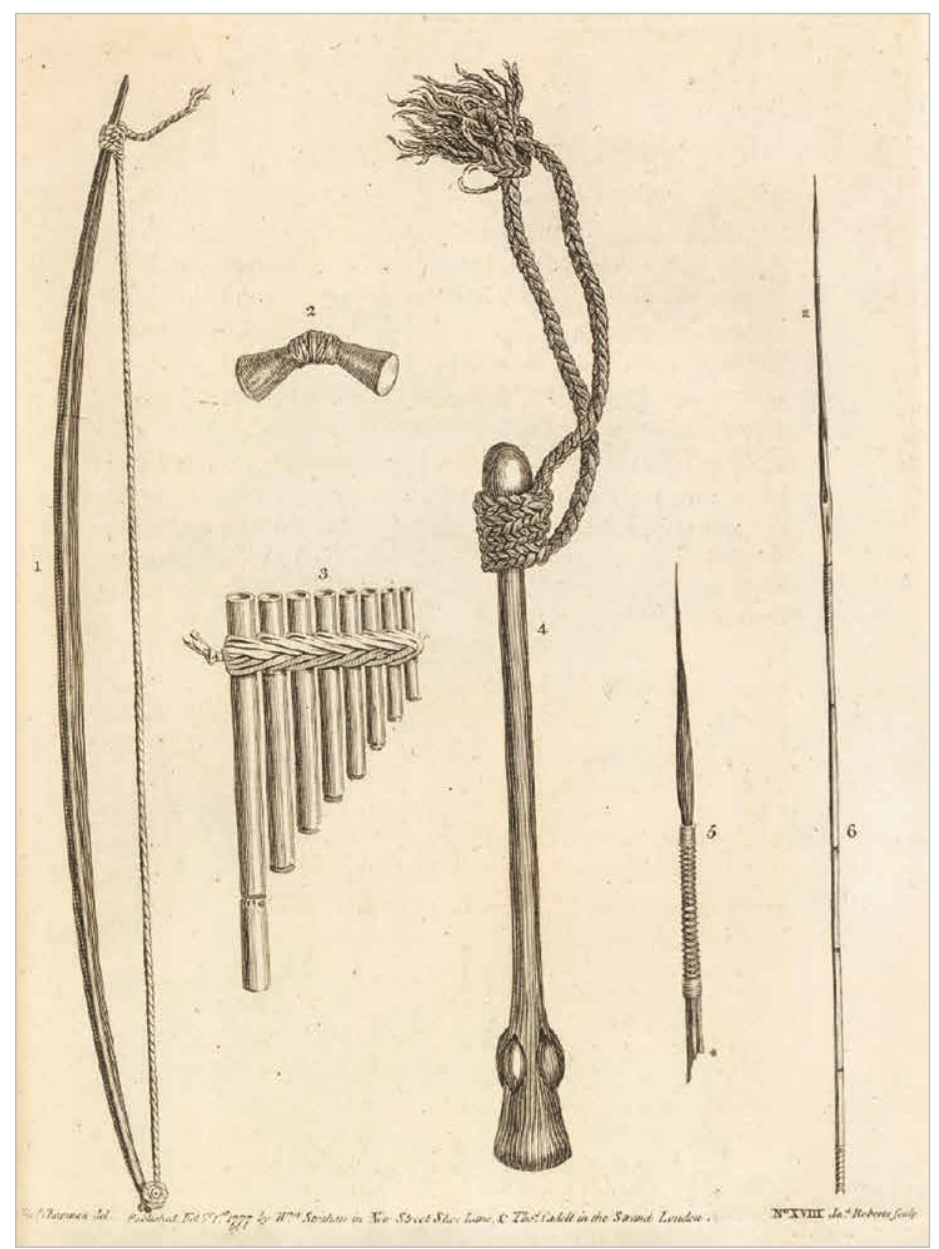

Figure 5. Weapons, \&c at Mallicolo and Tanna, engraving by J. Roberts after Charles Chapman (Cook 1777: plate 18). 
Resolution's officers and scientists with a least a passing classical education also would have understood panpipes' bucolic associations, if not the details of Ovid's Metamorphoses origin story of the virginal nymph Syrinx who, when chased by lusty Pan, transformed into river reeds, which Pan transformed into pipes so that he could play her, one way or another. Although similar reed, bamboo or bone wind instruments have been found in China, Southeast Asia, India, Africa, Egypt, Turkey, the Americas, Tonga and elsewhere in Melanesia (Kaeppler 1974; Zemp 1981), bundled or rafted pipes specifically evoked Pan and classical roots. Panpipes signalled pastoral harmonies, Arcadian climes inhabited by men imbued with better natures or essential sagacity, or both. Papageno, in Mozart's 1791 Magic Flute, comes on stage with panpipes and stage props that present him "as a spontaneous man at one with organic nature ... From an Enlightenment perspective, his structure can readily be imagined as part of a natural order, accessible to all, without the intervention of culture or reflection, and grounded on a natural condition of reason" (Subotnik 1991: 134; see also Cole 2005: 4).

Panpipes had echoed classical ideals since the Renaissance. The frontispiece of a 1532 edition of the Aeneid, for example, featured poet Virgil holding a large syrinx (Miziolek 1999: 98). Virgil's Eclogues "paved the way for the Arcadian myth" (p. 99), a vision that, "with the herdsmen singing and playing syrinx, became one of the topoi ['motifs'] of European culture" (p. 104). This topoi shaped European visions of the peoples that Cook and party encountered in the Pacific. "The Greek revival in Europe", Smith notes, "is conveniently contemporaneous with the European pre-colonisation period in the Pacific" (1992: 213).

Smith suggests that European visions of noble savages in the Pacific quickly eroded after 1795 (1985: 174), replaced by more invidious representations. Nonetheless, Cook voyage chronicles and Hodges's graphics continued to influence subsequent visions of islanders for several decades. Subsequent voyagers, for example, coming to Tanna after Cook likewise were pleased to obtain panpipes as well as the island's bellicose clubs and spears. Russian explorer Vasily Mikhailovich Golovnin arrived next in July 1809, his ship Diana mooring in Port Resolution for a few days (Barratt 1990). Golovnin had on board a copy of Georg Forster's A Voyage Round the World, which directed his observations. He, too, described island panpipes and clubs, appreciating in particular the latter: "The best work of the Tannese is undoubtedly their clubs which, even though made of extremely hard wood, are well finished" (p. 69). Alongside clubs, he reported, the Tannese "also have a variety of musical instruments consisting of four, six, or eight pieces of reed, bound together in order of length ... The pipes are moved along the lips and, as the player blows, an awkward whistling is produced" (p. 69). Golovnin traded for a few examples. Like the Forsters, he also collected Nafe language words (pp. 70-72), including nep 'club' and, for 'panpipes', 
nau - close enough to today's term tarhei nau 'series of bamboo' in the Nafe (Kwamera) language spoken around Port Resolution. ${ }^{5}$

After Diana sailed away in 1809, numbers of sandalwooders, traders and whalers refreshed at Port Resolution in the 1820s and 1830s, but few of these visitors generated much ethnographic description or graphic imagery. Traffic increased in the 1840s thanks to the murder of London Missionary Society luminary John Williams on Erromango in 1839. Williams left Sāmoan teachers at Port Resolution the day before he died and, capitalising on his murder, the Society sent two British missionaries to Tanna in 1842. George Turner and Henry Nisbet endured six months of increasing hostility at Port Resolution before fleeing in January 1843. Turner, in later years, published his memoirs including his ethnographic observations $(1861,1884)$. In these, he too noted Tanna's "clubs, bows and arrows, and spears" (1861: 81) and also its "Pandean pipe, with seven or eight reed pipes, varying in length" (1884: 312$)$.

Hodges's views of Tanna and their subsequent modifications and reuses dominated the graphic marketplace until the 1830 s, even while notions of Greeks-in-the-Pacific and/or noble savages were evaporating. Cook voyage illustrations proved immediately popular, available for purchase at Strahan and Cadell (later W. and A. Strahan), London, publishers of all three Cook voyage accounts (Hawkesworth 1773). Those living outside the city or who couldn't afford the official prints enjoyed reworked variations of Hodges's images featured in a number of contemporary magazines (The Gentleman's Magazine, The London Magazine, The Universal Magazine of Knowledge and Pleasure, The Lady's Magazine, among others). They also found these in cheaper abridged accounts of Cook's voyages and in popular "universal geographies", although imagery from the first and third voyages proved more popular than that from the second (Anderson 2017; Morrell 2010).

In France and elsewhere in Europe, Hodges's work was similarly recycled and repurposed, notably in "costume" books that depicted ethnic types from around the world. By the mid-eighteenth century, costume had come to mean "both clothing and custom" (Morrell 2010: 18-19). Creators of these compendia offered exaggerated claims "in title pages or prefaces that their books contained new material and original work", but "what is striking is the longevity of some images and their apparent resistance to new information" (p. 98). Jacques Grasset de Saint-Sauveur, an occasional diplomat and prolific author, born in Montréal, was one of the first to publish redrawn Hodges imagery, including portraits of a Tanna man and woman in several collections (see Collins 1984). In Grasset de Saint-Sauveur's 1796 Encyclopédie des Voyages, J. Laroque's engravings of a Tanna man and woman appear as separate portraits (Figs 6 and 7). They appear again in his 1806 Voyages Pittoresques dans les Quatre Parties du Monde, standing together under a coconut palm in a single, somewhat reworked print. 
Grasset de Saint-Sauveur, or perhaps his ghostwriter, Jean-François Cornu, composed a Tanna précis that celebrated the island's happiness, hospitality and generosity, along with its rich soils and beautiful nature. The author, who listed island weaponry (clubs, bows, spears) and also precious panpipes, clearly consulted Georg Forster's account, which was the only one to describe the latter: "These people passionately love music, and please themselves constantly with song; their musical instruments are the same as at Tahiti; but they have one, composed of eight reeds, that they cherish above all others. Their melody is very agreeable; they gather under the trees, and create delicious concerts" (Grasset de Saint-Sauveur 1796: 4 [Tanna section], my translation).

Like sampled voyage texts, Grasset de Saint-Sauveur or his engraver Jacques Laroque blended several elements from Hodges's originals to create derivative illustrations, as Morrell has noted:

Saint-Sauveur borrows fragments from various sources-while a number of the voyage images were only head and shoulders portraits, Saint-Sauveur either makes up a body or adapts one from a general scene. For example, the heads of Saint-Sauveur's Homme et Femme de l'Isle de Tanna (Man and Woman of Tanna) ... are based on engravings of two of William Hodges's head-and-shoulder portraits [Figs 1 and 2 above], but some of the full-body elements are taken from a group of people in View in the Island of Tanna after Hodges. (Morrell 2010: 52; see Morrell 2012)

The Tanna man, leaning on his gigantic club (Fig. 6), echoes the contrapposto standing figure in Hodges's View (Fig. 4). Grasset de Saint-Sauveur also augmented Hodges's originals, placing panpipes in the woman's hand, although Georg Forster's account indicated that these were played by men (Forster 2000: 535). He read Forster's panpipes anecdote, he found their engraved image in Cook (1777) and he transformed Hodges's portrait into a musical Tanna woman.

Grasset de Saint-Sauveur's brandished panpipes continued to feature in subsequent island imagery. They appeared again in Jean-Gabriel Charvet's celebrated 1804 papier peint wallpaper, Sauvages de la Mer Pacifique (strip seven) (Morrell 2010: 62). Tanna man and woman here are seated together, panpipes dangling from her hand while the man's club lies between his legs. Smoke rises from a volcano, probably Tanna's Iasur, in adjacent strip eight. Panpipes and club appear again, more elegantly drawn, in an 1803 Dutch geographic encyclopaedia, De Mensch, Zoo Als hij Voorkomt op den Bekenden Aardbol (The Human Being as He Appears on the Known Globe) (Stuart 1803; see Morrell 2010: 67). The man, in this, has retrieved and plays the panpipes, with the club now in his left hand and a bow over his shoulder. The woman regains a child, as in Hodges (Figs 2 and 4), and 


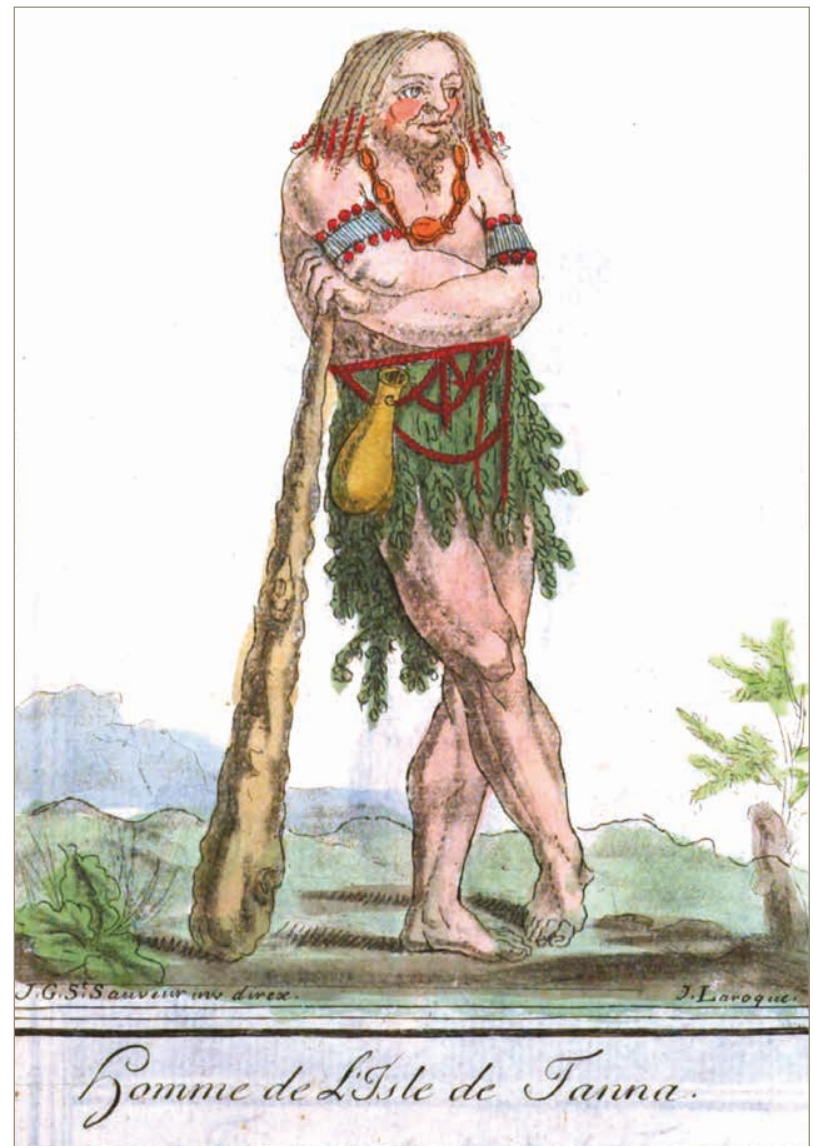

Figure 6. Homme de l'Isle de Tanna, J. Grasset de Saint-Sauveur (1796).

has picked up a basket. Iasur volcano continues conspicuously to erupt in the background. But, in the engraving's caption, the two figures represent all of the Nieuwe Hebriden, not just Tanna (Fig. 8). The burdened woman coming along behind, who lugs both basket and child, would remain a trope in subsequent mission imagery of islanders.

Panpipes jump back into the woman's hand in an 1818 print from an inexpensively produced British costume book written principally for women. This offered "beautifully coloured" man and woman portraits from around the 


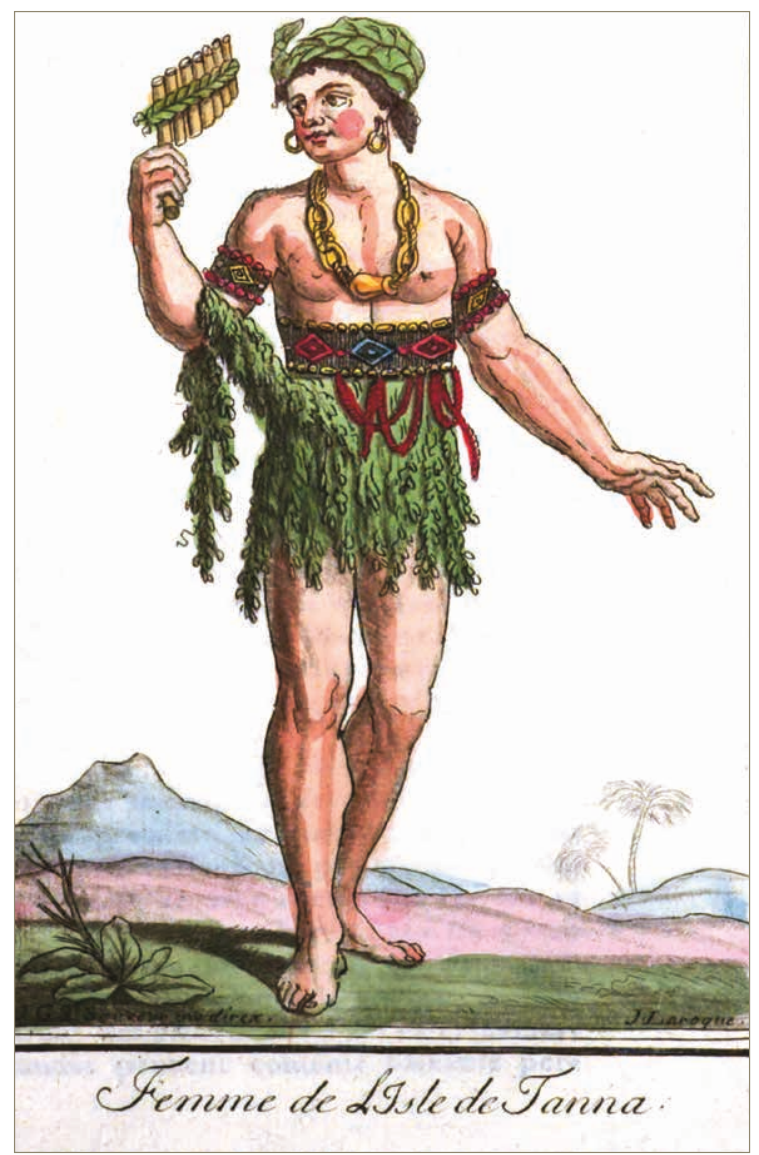

Figure 7. Femme de l'Isle de Tanna, J. Grasset de Saint-Sauveur (1796).

world (Fig. 9) (Venning 1818: facing p. 140). Although the background has been reworked, this image, too, clearly derives from Hodges via Grasset de Saint-Sauveur, as the two figures stand next to a coconut palm and the man (here wearing a turban) leans again on his enormous club.

Nature, even in this elementary reproduction, is yet idyllic and the couple's stance is contrapposto and heroic, or at least their melodious panpipes continue to counterbalance the worrisome club. Twenty years later, however, when missionary imagery of Tanna began to circulate, European visions had 

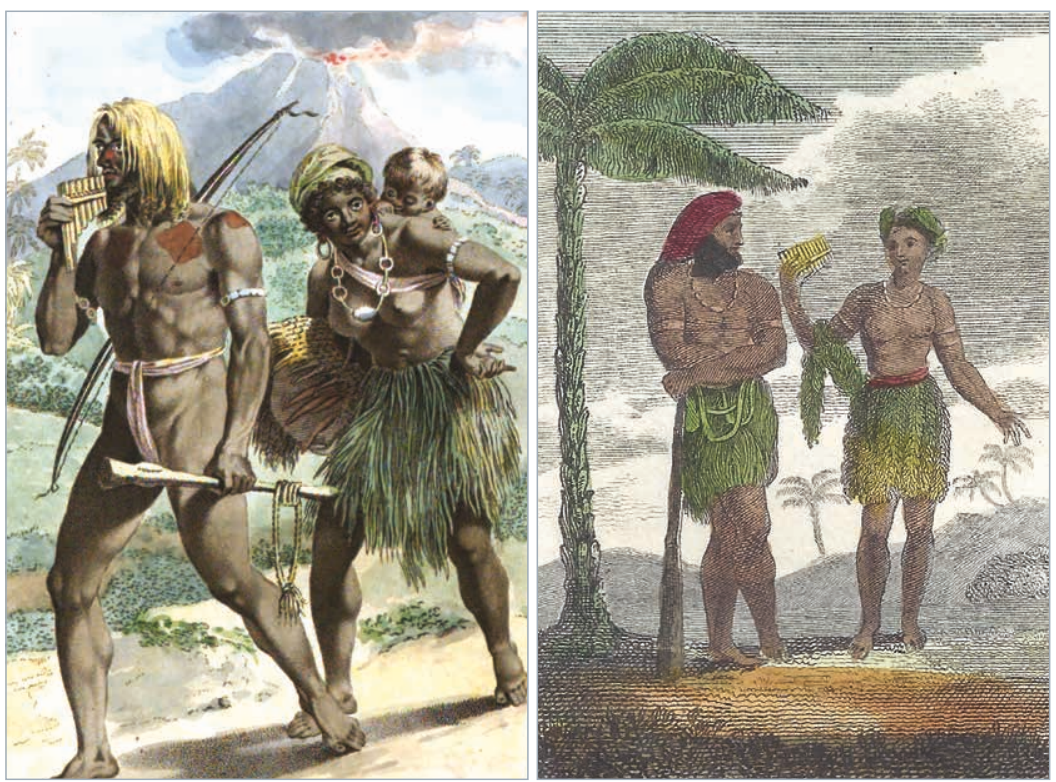

Figure 8. (left) Nieuwe Hebriden, engraved by Louis Portman after Jacques Kuyper (Stuart 1803: facing p. 100).

Figure 9. (right) Man \& Woman of the Isle of Tanna (Venning 1818: facing p. 140).

changed. Clubs and other weaponry remained while panpipes disappeared. Their sweet, classical harmonies would shade the Christian message. London artist George Baxter's 1841 coloured oil print The Reception of the Rev. J. Williams, at Tanna, in the South Seas, the Day Before He Was Massacred (Fig. 10), for example, foregrounded a man with a notable club, with plenty of spears rising up behind. Its companion piece, Massacre of the Lamented Missionary The Rev. J. Williams, and Mr. Harris, featured even larger and more vigorously wielded clubs.

Mission propaganda liked to play up the cruel dangers that bravely intrepid missionaries who wandered the Pacific might encounter. It would for years circulate darkness versus light, pre- and post-conversion imagery in which the gospel improved and civilised (Lindstrom 2016; Smith 1985: 318). Saved islanders laid down their clubs for garden tools and hymnals. Nineteenth-century Presbyterian missionaries who came to Tanna enthusiastically cultivated hymn singing among new converts, but would 


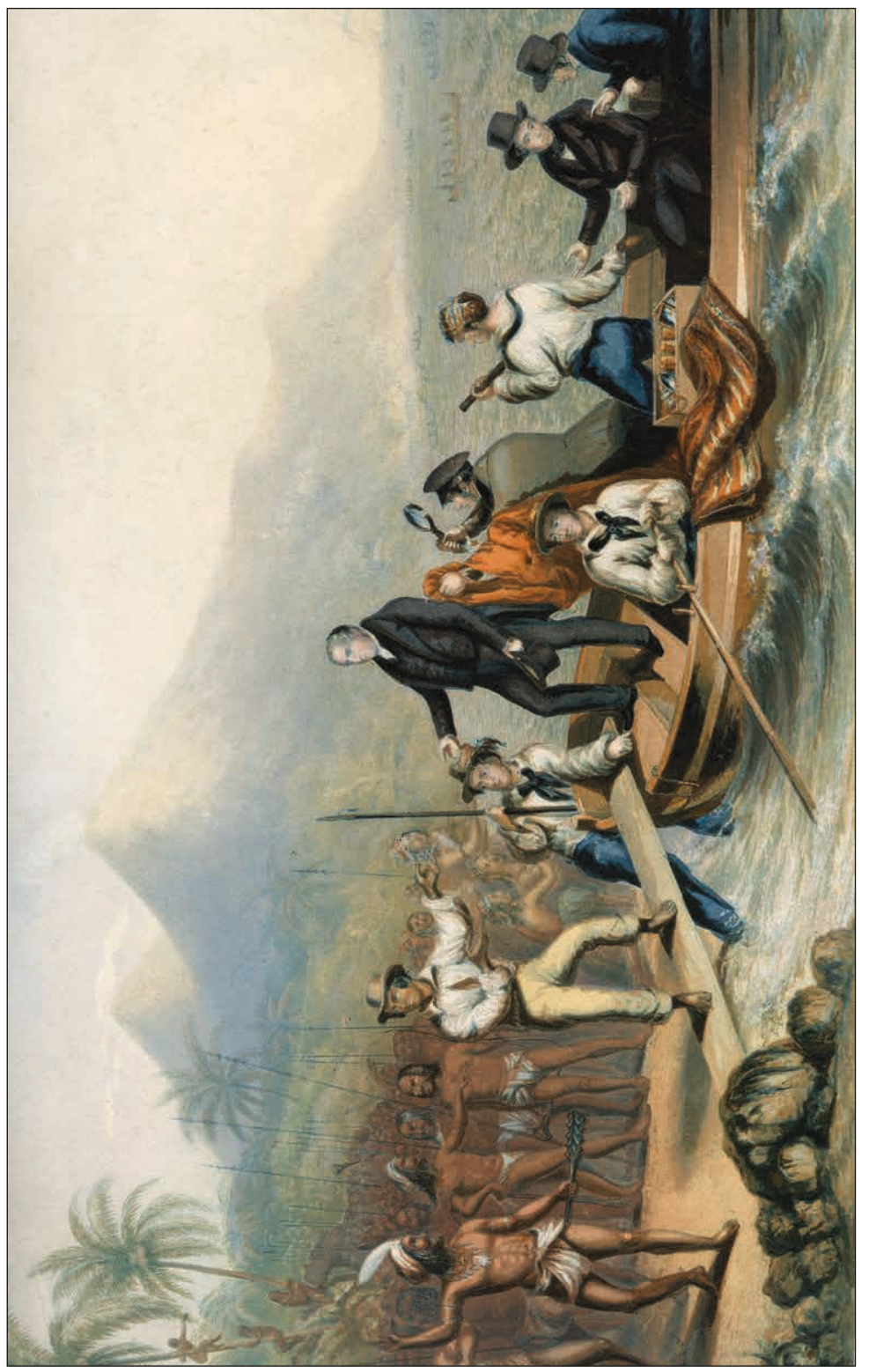

ป⿱艹 
have disapproved of panpipe music's associations with ancestor spirits. Clubs resonated differently. Although Christian imagery, like Hodges, favoured island family groupings and mothers with child, men in mission iconography continued to display significant weaponry, as in one Tanna family depiction (Natives of Tanna) that illustrated George Turner's mission memoir (Fig. 11) (Turner 1861: 76). In addition to his club, father comes heavily armed with a spear and a slingshot tucked into his coconut armband. Mother, though, has lost the panpipes.

Also by the 1840s, pre-Darwinian evolutionary discourse paralleled Christian rejection of onetime romantic, if unsaved, savages and unbedevilled, bountiful island environments. Racial hierarchies that presumed different levels of civilisation solidified during the first half of the nineteenth century. Racial and cultural categories that discriminated Polynesians from southwest Pacific Melanesians emerged in the 1820s (Douglas 2008: 716-17; see Jolly 1992: 334). Cook, Hodges, the Forsters and others on Tanna in 1774 made few invidious racial distinctions between islanders they met at Port Resolution and others they had previously encountered in Tahiti, Tonga, Cook Islands or New Zealand - especially since some of those they met at Port Resolution came from neighbouring Futuna, a Polynesian-speaking Outlier.

Solidifying nineteenth-century theories of human progress, however, eventually "greatly sharpened the antithesis between savagery and civilization" and, within these, "savages were nevertheless generally conceived



Figure 11. Natives of Tanna, engraved by William Dickes (Turner 1861: 76). 
in negative terms by progressionists and degenerationists alike" (Stocking 1987: 36; see Morrell 2010: 93). Once noble, Greek-like savages reappeared as simply savage. The 1841 Nouvelle Bibliothèque des Voyages Anciens et Modernes, which included an abridged French translation of Cook's account, offered a novel Tanna image (Duménil 1841, after p. 167). ${ }^{6}$ Rather than Tanna man or woman, this depicts Naturels de l'Ile Tanna. Two of these naturels, more huddled in the background, hold a clutch of fish and a simple spear (Fig. 12). Panpipes and even clubs have vanished. Virtual Greek becomes virtual ape.

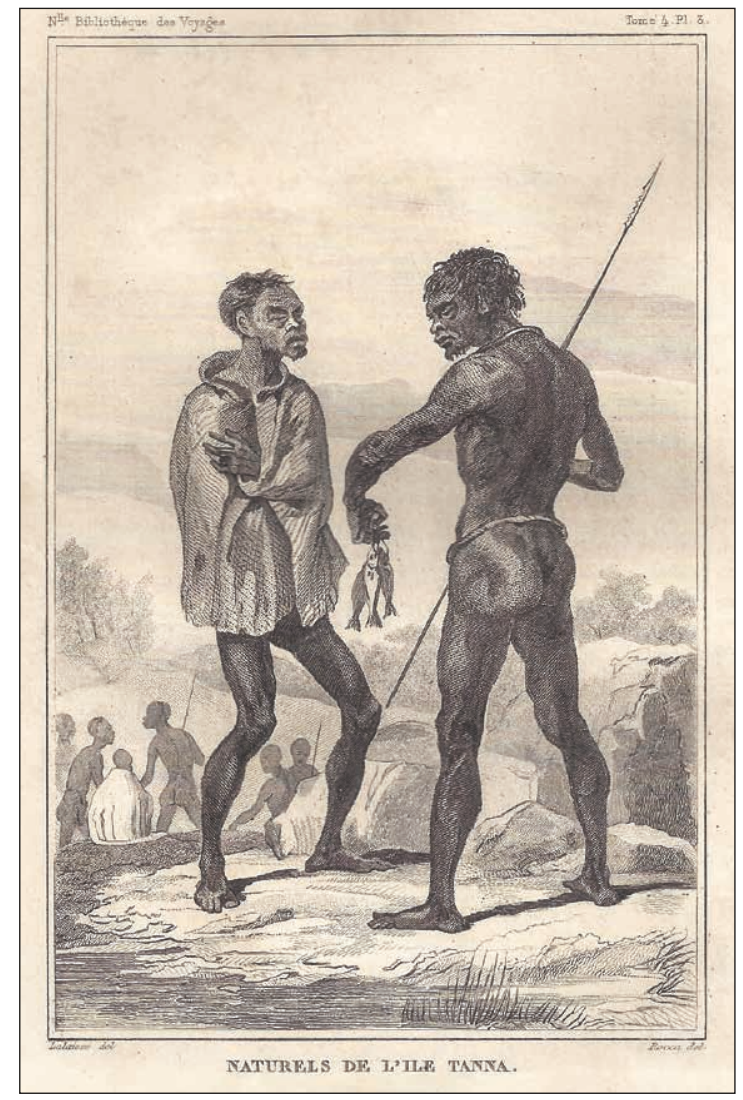

Figure 12. Naturels de l'Ile Tanna, engraved by M. de Rocca after François Lalaisse (Duménil 1841, vol. 4, plate 3). 


\section{MUSICAL NATURES}

The Tanna island visions that Hodges and his copyists produced have long ago morphed into more complicated constructions. The panpipe and the club, musicality and violence, dominated European visions of Tanna from Cook's stopover at Port Resolution in 1774 through the 1830s. Classical allusions after these years evaporated as social evolutionary theory displaced eighteenthcentury tropes of noble savagery. Missionaries, beginning in the 1840s, overdrew panpipe imagery in novel portrayals of islanders, often grouped in nuclear families, in dire need of salvation. Today's island imagery (e.g., in postcards and tourist brochures) depicts neither panpipes nor clubs. Instead, it features gorgeous nature, the fiery Iasur volcano, fascinating customs of dance and dress, and friendly people. ${ }^{7}$

Although panpipes and clubs long ago disappeared from island depictions, Hodges's initial Arcadian topoi have bled into contemporary views, at least on some infrastructural level. Common presumptions that simpler, often darker, peoples possess natural rhythm and inherent musicality have significant economic value. Today's visitors may be unschooled in the expeditionary engravings of Hodges and his copyists, but presumptions of island musicality persist. Vanuatu's Office of Tourism boasts that "music surrounds our islands like the ocean" (https://vanuatu.travel/en/experience/artists). If few tourists come to Tanna hoping to hear faint whistlings of island panpipes, many do expect to watch and photograph island dance festivals (Lindstrom 2015). Port Vila's annual Fest'Napuan music festival attracts an enthusiastic audience of locals and tourists. Up in the Solomon Islands, remarkable panpipe orchestras entertain tourists booked into Honiara's hotels (https://www.visitsolomons.com. $\mathrm{sb}$ /about-the-solomon/music-art/). And, elsewhere in Vanuatu, tourist promoters eye the attractive possibilities of Banks Islands women's "water music" as a touristic sensation (Dick 2014). Naturally musical islanders are with us still.

On Tanna, unlike clubs, the manufacture of which is only occasional, young men and boys continue to make and play tarhei nau. ${ }^{8}$ They lace together, with pandanus fibre, a set of graduated segments of bamboo, usually seven or eight of these according to the maker's whim, in several different styles (Ammann 2012: 93-96). Panpipes come and go in flushes. Forgotten and laid aside for months or years, something will spark a revival, and one newly made example will trigger desire for many more. Young men puff out their own compositions or rehearse songs that community groups have performed previously during nupu circle dances or during occasional regional nakwiari exchanges of dance, pigs and kava. Panpipe performance is casual and others tend not to sing along. Instead, pipers entertain village audiences, or sometimes only themselves while walking alone down island roads and trails. A few islanders also make and play flutes (kwataratara), constructed from a longer and wider single segment of bamboo. 
***

Panpipes continue to feature in islanders' own visions, as they once did in European, although these differ from Hodges's and Grasset de SaintSauveur's classical fancies. Rather, panpipes on Tanna adumbrate a community's tuneful repertoires and spiritual presence. The plaintive tones of bamboo flutes and panpipes impel ancestral spirits to attend and listen. "The main function of panpipe music", reports musicologist R. Ammann, "lies in its power to help the yam grow. In the interior of Tanna the panpipes are therefore only played during the months when the yam is growing in the garden: from April to July and during the planting season from July to November" (2012: 94). ${ }^{9}$ The annual yam harvest at Port Resolution runs these days between March and June, while preparing fields, constructing yam mounds and planting seed yams occurs in August and September before the rainy season arrives. Georg Forster's Tanna friends, in August 1774, might indeed have been puffing their panpipes to entice ancestral spirits to protect and nurture newly planted yams. Or, as Ammann also notes, "a second function is to send courting messages to an admired girl" (p. 94). And certainly also to entertain and cultivate new friends, even strange visitors from overseas who come ashore with persistent musical visions that continue to echo and resonate within island encounters.

\section{ACKNOWLEDGEMENTS}

I thank the Journal's anonymous reviewers and art historians Kirsten Olds and Prue Ahrens for helpful comment, and friends on Tanna for sharing panpipes and their tunes (although no clubs) with me.

\section{NOTES}

1. For recent retellings of Cook's voyages, see Salmond (2003), Thomas (2004) and Douglas (2008).

2. Schneiderman suggests that George William Anderson was likely a pseudonym, a ploy that publisher Alexander Hogg "employed in a number of his publications in order to endow these inexpensive serials with an aura of authoritative knowledge" (2014: 2). Three portraits that Hodges made of Tannese men survive. One drawing, in red chalk and pencil, was a pre-engraving study for Man of the Island of Tanna (Fig. 1). A second in charcoal, and a third in red chalk, depict island men in a less classically informed, more naturalistic style (Joppien and Smith 1985: 96-97, 229-30).

3. On Tanna, spears were actually javelins or darts in that men threw these more than they used them to stab some adversary.

4. Only Georg Forster described Tanna panpipes; other voyage journalists - including his father, Johann, Cook, Anders Sparrman, William Wales, and John Marra — did not remark panpipes in their accounts of Resolution's layover in the harbour. 
5. Nau also means 'knife' and the 'bamboo' from which knives once were made; a stalk of bamboo is teki nau 'skin of bamboo'. Two centuries later, Golovnin's word list (1990: 70-71), although rudimentary and including several terms from Futuna-Aniwa, the language of Tanna's Polynesian-speaking neighbours, is remarkably accurate.

6. Although the title pages list P. Duménil as the compendium's editor, CharlesEdmond Duponchel wrote, translated or otherwise contributed to the volumes' text.

7. We can only guess what implements, beyond panpipes and clubs, eighteenth- and nineteenth-century islanders might have chosen to portray themselves. Many contemporary Tanna selfies posted on Facebook include family members, garden and food items and kava cups and bowls.

8. Islanders do make several sorts of dance implements, which men flourish during nakwiari dance festivals, but these differ from traditional island club types.

9. Ammann misattributes Georg Forster's panpipes anecdote to his father Johann.

\section{REFERENCES}

Agnew, Vanessa, 2001. A Scots Orpheus in the South Seas: Encounter music on Cook's second voyage. Journal for Maritime Research 3 (1): 1-27.

Ammann, Raymond, 2012. Sounds of Secrets: Field Notes on Ritual Music and Musical Instruments on the Islands of Vanuatu. Munich: LIT, Klang Kultur Studien.

Andersen, Johannes C., 1932. Maori Music with its Polynesian Background. Part 1. Memoir no. 10, Supplement to the Journal of the Polynesian Society 41 (1): 1-30.

Anderson, George William, 1784-1786. A New, Authentic, and Complete Collection of Voyages Round the World. London: Alexander Hogg.

Anderson, Jocelyn, 2017. Elegant engravings of the Pacific: Illustrations of James Cook's expeditions in British eighteenth-century magazines. British Art Studies 7. http://dx.doi.org/10.17658/issn.2058-5462/issue-07/janderson

Barratt, Glynn, 1990. Melanesia and the Western Polynesian Fringe. Vancouver: University of British Columbia Press.

Campbell, I.C., 1980. Savages noble and ignoble: The preconceptions of early European voyagers in Polynesia. Pacific Studies 4 (1): 45-59.

Cole, Malcolm S., 2005. Monostatos and his "sister": Racial stereotype in Die Zauberföte and its sequel. The Opera Quarterly 21 (1): 2-26.

Collins, Roger D.J., 1984. Jacques Grasset de Saint-Sauveur, Turnbull Library Record 17 (1): $28-41$.

Cook, James, 1777. A Voyage towards the South Pole, and Round the World, Performed in His Majesty's Ships the Resolution and Adventure. London: W. Strahan and T. Cadell.

1961. The Journals of Captain James Cook on His Voyages of Discovery. Vol. II. Edited by J.C. Beaglehole. Hakluyt Society, Extra Series No. 25. New York: Cambridge University Press.

Dick, Thomas, 2014. Vanuatu water music and the Mwerlap diaspora: Music, migration, tradition, and tourism. AlterNative: An International Journal of Indigenous Peoples 10 (4): 392-407. 
Douglas, Bronwen, 2008. Voyages, encounters, and agency in Oceania: Captain Cook and indigenous people. History Compass 6 (3): 712-37.

Duménil, P., 1841. Nouvelle Bibliothèque des Voyages Anciens et Modernes. Vol. 4. Paris: M.M. Firmin Didot Frères.

Forster, George, 2000. A Voyage Round the World. Edited by Nicholas Thomas and Oliver Berghof. Honolulu: University of Hawai'i Press.

Grasset de Saint-Sauveur, Jacques, 1796. Encyclopédie des Voyages. Paris.

-1806. Voyages Pittoresques dans les Quatre Parties du Monde, ou Troisième Édition de l'Encyclopédie des Voyages. Paris.

Guest, Harriet, 1989. The great distinction: Figures of the exotic in the work of William Hodges. Oxford Art Journal 12 (2): 36-58.

Hawkesworth, John, 1773. An Account of the Voyages Undertaken by the Order of His Present Majesty for Making Discoveries in the Southern Hemisphere. London: W. Strahan and T. Cadell.

Hoare, Michael E., 1967. Johann Reinhold Forster: The neglected "philosopher" of Cook's second voyage (1772-1775). Journal of Pacific History 2 (1): 215-24. (ed.), 1982. The Resolution Journal of Johann Reinhold Forster, 1772-1775. Vol. 4. London: The Hakluyt Society, Cambridge University Press.

Irving, David, 2005. The Pacific in the minds and music of Enlightenment Europe. Eighteenth-Century Music 2 (2): 205-29.

Jolly, Margaret, 1992. "Ill-natured comparisons": Racism and relativism in European representations of ni-Vanuatu from Cook's second voyage. History and Anthropology 5 (3/4): 331-64.

2009. The sediment of voyages: Re-membering Quirós, Bougainville and Cook in Vanuatu. In M. Jolly, S. Tcherkézoff and D. Tryon (eds), Oceanic Encounters: Exchange, Desire, Violence. Canberra: ANU Press, pp. 57-111.

Joppien, Rüdiger and Bernard Smith, 1985. The Art of Captain Cook's Voyages. New Haven, CT: Paul Mellon Centre for Studies in British Art, Yale University Press.

Kaeppler, Adrienne L., 1974. A study of Tongan panpipes with a speculative interpretation. Ethnos 39 (1-4): 102-28.

1978. Polynesian music, Captain Cook, and the Romantic movement in Europe. Music Educators Journal 65 (3): 54-60.

Kelly, Celsus, 1966. La Austrialia del Espíritu Santo: The Journal of Fray Martín de Munilla O.F.M. and other documents relating to The Voyage of Pedro Fernández de Quirós to the South Sea (1605-1606) and the Franciscan Missionary Plan (1617-1627). Cambridge: The Hakluyt Society, Cambridge University Press.

Lindstrom, Lamont, 2015. Cultural heritage, politics, and tourism on Tanna, Vanuatu. In E. Hviding and G. White (eds), Pacific Alternatives: Cultural Politics in Contemporary Oceania. Oxford: Sean Kingston, pp. 180-99.

2016. Darkness and light in black and white: Traveling missionary imagery from the New Hebrides. In J. Taylor and K. Alexeyeff (eds), Touring Pacific Cultures: Mobility, Engagement and Value. Canberra: ANU Press, pp. 31-55.

Miziolek, Jerzy, 1999. Virgil with panpipes: Observations on the iconography of an Italian panel from the Langkoronski Collection. Fontes 2 (3/4): 97-116.

Morrell, Vivienne, 2010. "To the Curious Enquirer": Depictions of Pacific Peoples in Popular Illustrated Books from Paris and London c.1775-1810. MA thesis, Victoria University of Wellington. 
2012. "To know the world from home you need not stray": Exotic depictions of Oceanic peoples in popular books, c.1775-1810. Turnbull Library Record 44 (1): 19-35.

Salmond, Anne, 2003. The Trial of the Cannibal Dog: The Remarkable Story of Captain Cook's Encounters in the South Seas. New Haven, CT: Yale University Press.

Schneiderman, Kara, 2014. Terrestrial Paradises: Imagery from the Voyages of Captain Cook. MA thesis, University of Miami.

Smith, Bernard, 1985. European Vision and the South Pacific. 2nd ed. New Haven, CT: Yale University Press.

1992. Imagining the Pacific in the Wake of the Cook Voyages. New Haven, CT: Yale University Press.

Steele, Joshua, 1775. Account of a Musical Instrument, which was brought by Captain Fourneaux from the Isle of Amsterdam in the South Seas to London in the Year 1774, and given to the Royal Society; Explanation of the system of musical pipes, brought from the Isle of Amsterdam in the South Sea, by Captain Fourneaux, to London, anno 1774, from experiments made by Mr. Steele. Philosophical Transactions of the Royal Society 65: 67-71.

Stocking, George W., Jr, 1987. Victorian Anthropology. New York: The Free Press.

Subotnik, Rose Rosengard, 1991. Whose Magic Flute? Intimations of reality at the gates of the Enlightenment. 19th-Century Music 15 (2): 132-50.

Stuart, Martinus, 1803. De mensch, zoo als hij voorkomt op den bekenden aardbol. Amsterdam: Johannes Allart.

Thomas, Nicholas, 2004. Cook: The Extraordinary Voyages of Captain James Cook. New York: Walker Publishing Co.

Turner, George, 1861. Nineteen Years in Polynesia: Missionary Life, Travels and Researches in the Islands of the Pacific. London: John Snow.

1884. Samoa: A Hundred Years Ago and Long Before. London: Macmillan and Co.

Venning, Mary Anne, 1818. A Geographical Present: Being the Principal Countries of the World. 2nd ed. London: Barton, Harvey and Darton.

Zemp, Hugo, 1981. Melanesian solo polyphonic panpipe music. Ethnomusicology 25 (3): 383-418.

\section{AUTHOR CONTACT DETAILS}

Lamont Lindstrom, Department of Anthropology, University of Tulsa, 800 S. Tucker Dr., Tulsa, Oklahoma 74104, USA. Email: lamont-lindstrom@utulsa.edu 